\title{
OUTCOME OF PATIENTS DIAGNOSED WITH END-STAGE RENAL DISEASE REQUIRING INTENSIVE CARE UNIT ADMISSION AT A SINGLE CENTER IN PAKISTAN
}

\author{
Mehr Afroz, Syed Firqan Zafar, Ejaz Ahmad, Syed Fazal Akhter \\ Sindh Institute of Urology and Transplantation, Karachi Pakistan
}

\begin{abstract}
Objective: To determine the outcome of patients with end-stage renal disease requiring intensive care unit admission at a single center in Pakistan.

Study Design: Prospective observational study.

Place and Duration of Study: Nephrology Intensive Care Unit of Sindh Institute of Urology and Transplantation, Karachi, Pakistan, from Sep 2018 to Jan 2019.

Methodology: After approval from the research advisory board of Sindh Institute of Urology and Transplantation, all consecutive adult patients ( $\geq 18$ years) of either gender with end-stage renal disease with glomerular filtration rate (GFR) $<15$ $\mathrm{ml} / \mathrm{min} / 1.73 \mathrm{~m}^{2}$ and bilateral irreversible structural abnormalities of kidneys on ultrasound who required intensive care unit admission were included in the study.

Results: Among 205 patients, 117 (57.1\%) were males. The mean age was $44.16 \pm 14.18$ years. Hypertension, 125 (61\%), was most common co-morbidity, followed by diabetes in 73 (35.6\%) cases and other rare conditions. Regarding indications for intensive care unit admission, severe metabolic acidosis $68(33.25 \%)$ was the most common indication, followed by altered sensorium in $43(21 \%)$, sepsis in $36(17.6 \%)$ and others. Overall intensive care unitmortality rate was 31.7\% (63/205). The total Sequential Organ Failure Assessment score of alive patients, on $1^{\text {st }}$ and last day was 88.29 and 71.58, respectively, while of expired patients was 134.68 and 170.68, respectively. Significant association of mortality with diabetes and hypertension was observed.

Conclusion: Higher mortality rates were observed for end-stage renal disease patients requiring intensive care unit admission in our set-up. Higher Sequential Organ Failure Assessment scores were observed both on admission and on the last day among patients who expired.
\end{abstract}

Keywords: End-stage renal disease, Intensive care unit, Mortality, Sofa score.

This is an Open Access article distributed under the terms of the Creative Commons Attribution License (https://creativecommons.org/licenses/by-nc/4.0/), which permits unrestricted use, distribution, and reproduction in any medium, provided the original work is properly cited.

\section{INTRODUCTION}

The incidence and prevalence of end-stage renal disease (ESRD) is on the rise all over the world, mainly due to rising prevalence of diabetes mellitus, hypertension and increasing age, with significant increase observed in the developing world ${ }^{1-3}$. As reported for Pakistan, the annual incidence of new cases is $>100$ per million ${ }^{4}$. According to Kidney Diseases: Improving Global Outcomes (KDICO) criteria ${ }^{5}$, ESRD is defined as an irreversible decline in glomerular filtration rate (GFR) to $<15 \mathrm{ml} /$ minute $/ 1.73 \mathrm{~m}^{2}$. A large set of patients have been reported to undergo emergency dialysis even with a short history of ESRD whose etiology was unknown ${ }^{6}$. ESRD patients with intensive care unit (ICU) admission are at a higher risk of morbidity as well as mortality even after discharge in the form of new cardiovascular events, malnutrition and readmission to hospitals ${ }^{7,8}$. In our part of the world, basic health facilities are scarce, so there is significant number of patients who require ICU admission at the time

Correspondence: Dr Mehr Afroz, Department of Nephrology, Sindh Institute of Urology and Transplantation, Karachi Pakistan

Received: 20 Nov 2019; revised received: 24 Nov 2019; accepted: 27 Dec 2019 of diagnosis of ESRD for the first time. Very few studies have reported the findings of outcomes of ESRD patients who were admitted in ICU, of which, even a smaller fraction reported mortality in these patients ${ }^{7}$. However, there are conflicting reports on the observed mortality rates in different studies ${ }^{7}$. The Sequential Organ Failure Assessment (SOFA) score is an assessment of patient's organs status during the ICU admission providing an estimate of morbidity and mortality risk and thus predicting an outcome for those who are critically ill ${ }^{9}$. The score assesses six different organ systems, i.e., respiratory, cardiovascular, hepatic, coagulation, renal and neurological systems. A study from Belgium reported that in those patients admitted to ICU, the mortality rate is estimated to be $50 \%$, if the score increases within the first 96 hours of admission, which falls to $27-35 \%$ if the score remains unchanged and $<27 \%$ if the score is decreased ${ }^{10}$.

We undertook this study to document the mortality rates of ESRD patients admitted to ICU in our set up as baseline data and to assess the role of SOFA scoring system in predicting short-term outcome this group of patients. 
The objective of this study was to determine the outcome of patients who were diagnosed as ESRD and required ICU care, in terms of mortality and to determine the factors associated with increased mortality in these patients.

\section{METHODOLOGY}

This was a prospective observational study. The study protocol was reviewed and approved by research advisory board (CRP No. 020/18) of the Sindh Institute of Urology and Transplantation (SIUT), Karachi, Pakistan. SIUT is a tertiary referral center for kidney diseases and transplantation. This study was conducted at the Nephrology ICU of the SIUT, from September 2018 to January 2019. The total population of ESRD patients admitted to ICU is around 900 per year (internal data of SIUT). Based on previous estimate of ICU admission leadingto mortality rate of $22 \%$, margin of error of $5 \%$ and $95 \%$ confidence level, a sample size of 205 patients was required for this study ${ }^{8}$. Data available was of 205 patients as four (4) patients left against medical advice and moved to other hospitals. All consecutive adult patients ( $\geq 18$ years) of either gender who were labeled as ESRD on the basis of GFR $<15$ $\mathrm{ml} / \mathrm{min} / 1.73 \mathrm{~m}^{2}$ (calculated by MDRD/Cockcraft Gault equation) and bilateral irreversible structural abnormalities i.e., bilateral small size kidneys, loss of corticome-dullary distinction (echogenic normal size kidneys in diabetic patients) or bilateral polycystic kidneys on ultrasound kidney ureter and bladder (KUB) and who required ICU admission, were included in the study. Allchronic kidney disease (CKD) patients in ICU who were not class $5 \mathrm{~d}$ and not requiring renal replacement treatment (RRT) were excluded from the study.

Informed consent was obtained from patient or their surrogates. Patients' demographics, reasons for hospital admission, reasons for ICU admission, length of ICU stay, laboratory findings, and vital signs were recorded during their ICU stay. Twice daily visits were carried out by professors, with experience of over 25 years. All physical examinations at the time of admission and during the ICU stay were performed by them along with the primary researcher. Blood samples were collected on daily basis and sent to laboratory, which is well equipped, daily calibrated and supervised by experienced pathologists. Ultrasound KUB were performed by experienced and qualified radiologists of SIUT Radiology department. As co-morbidities are important in predicting mortality, all co-morbidities including hypertension, diabetes, polycystic kid- ney disease, renal stone disease, chronic interstitial nephritis and chronic sclerosing glomerulonephritis were recorded. Reasons for ICU admission, e.g., severe metabolic acidosis, convulsions, arrhythmias, shock, sepsis, altered sensorium, respiratory failure, pulmonary edema, uncontrolled hypertension and upper gastrointestinal (GI) bleed were recorded. Organ dysfunction was assessed using the SOFA score. The use of mechanical ventilation (MV) and inotropic support was also recorded.

Data sheets were completed by the primary researcher physician and reviewed and discussed with supervising faculty to maintain reliability and validity of data and also to reduce the possibility of bias. Statistical analysis was carried out by a statistician who was blinded to the study design. Statistical analysis was performedby using SPSS-25. All continuous data were presented as mean $\pm \mathrm{SD}$. Mann Whitney $U$ test was applied to compare median (IQR) values for quantitative variables. Chi-square/fisher's exact testswere used to compare categoricalvariables. $p$-value $\leq 0.05$ was considered statistically significant.

\section{RESULTS}

Among 205 patients, 117 (57.1\%) were males. Mean age of all patients was $44.16 \pm 14.18$ years. Among these, $142(69.3 \%)$ patients has established ESRD before admission to ICU, while 63 ((30.7\%) were diagnosed for the first time as ESRD on admission to ICU. Hypertension 125 (61\%) was most common comorbid condition followed by diabetic nephropathy 73 $(35.6 \%)$, renal stone disease $12(5.9 \%)$, chronic glomerulonephritis $5(2.4 \%)$, polycystic kidney disease $2(1 \%)$ and autoimmune disease $1(0.5 \%)$, as shown in table-I. As far as the reasons for ICU admission are concerned, severe metabolic acidosis $68(33.25 \%)$ was the main reason, followed by altered sensorium $43(21 \%)$, sepsis $36(17.6 \%)$, convulsions $26(12.7 \%)$, shock $32(9.8 \%)$, pulmonary edema $8(3.9 \%)$ and respiratory failure 3 (1.5\%). In all, $34(16.6 \%)$ patients required MV and 67 $(32.7 \%)$ needed inotropic support. In our study, 63 (31.7\%) expired during ICU admission and 140 (68.3\%) patients survived as shown in table-I. On univariate analysis, we found significant association of mortality with mechanical ventilation $(p<0.001)$, inotropic support $(p<0.001)$, diabetes $(p<0.05)$ and hypertension $(p<0.05)$, as shown in table-II. Significant differences among survivors and non-survivors werealso found for age $(p<0.05)$, SOFA score on $1^{\text {st }}$ day of admission $(p<0.001)$ and SOFA score on last day $(p<0.001)$, as shown in table-III. 
Table-I: Baseline characteristics of all patients $(n=205)$.

\begin{tabular}{|c|c|c|c|}
\hline Parameter of Interest & $\begin{array}{l}\text { Mean } \\
\pm \text { SD }\end{array}$ & $\begin{array}{l}\text { Median } \\
\text { (IQR) }\end{array}$ & n (\%) \\
\hline Age in years, & $\begin{array}{r}44.16 \\
\pm 14.8\end{array}$ & $\begin{array}{c}45(31- \\
55)\end{array}$ & - \\
\hline ICU Stay in days, & $\begin{array}{c}3.8 \pm \\
2.28\end{array}$ & $3(2-5)$ & - \\
\hline $\begin{array}{l}\text { Mean SOFA Score on } \\
1^{\text {st }} \text { day }\end{array}$ & $\begin{array}{c}9.58 \pm \\
3.76\end{array}$ & $9(0-21)$ & - \\
\hline $\begin{array}{l}\text { Mean SOFA Score on } \\
\text { last day }\end{array}$ & $\begin{array}{c}7.87 \pm \\
5.06\end{array}$ & $5(4-21)$ & - \\
\hline Sex, Males & - & - & $117(57.1)$ \\
\hline \multicolumn{4}{|l|}{ Co-Morbid Conditions } \\
\hline Hypertension & - & - & $125(61)$ \\
\hline Diabetic nephropathy & - & - & $73(35.6)$ \\
\hline Renal stone disease & - & - & $12(5.9)$ \\
\hline $\begin{array}{l}\text { Chronic glomeru- } \\
\text { lonephritis }\end{array}$ & - & - & $5(2.4)$ \\
\hline $\begin{array}{l}\text { Polycystic kidney } \\
\text { disease }\end{array}$ & - & - & $2(1)$ \\
\hline Autoimmune disease & - & - & $1(0.5)$ \\
\hline \multicolumn{4}{|c|}{ Reasons for ICU Admission } \\
\hline $\begin{array}{l}\text { Severe Metabolic } \\
\text { Acidosis }\end{array}$ & - & - & $68(33.2)$ \\
\hline Altered Sensorium & - & - & $43(21)$ \\
\hline Sepsis & - & - & $36(17.6)$ \\
\hline Convulsions & - & - & $26(12.7)$ \\
\hline Shock & - & - & $32(9.8)$ \\
\hline Pulmonary edema & - & - & $8(3.9)$ \\
\hline Respiratory Failure & - & - & $3(1.5)$ \\
\hline $\begin{array}{l}\text { Patients on Mechanical } \\
\text { Ventilation }\end{array}$ & - & - & 34 (16.6) \\
\hline $\begin{array}{l}\text { Patients Needing } \\
\text { Inotropic support }\end{array}$ & - & - & $67(32.7)$ \\
\hline Established ESRD & - & - & $142(69.3)$ \\
\hline $\begin{array}{l}\text { First time diagnosed } \\
\text { ESRD }\end{array}$ & - & - & $63(30.7)$ \\
\hline Survivors & - & - & $140(68.3)$ \\
\hline Non-Survivors & - & - & $65(31.7)$ \\
\hline
\end{tabular}

\section{DISCUSSION}

This study was planned to determine the outcomes among ERSD patients who were admitted to ICU for a variety of indications. In our study, the mean age of all ESRD patients was $44.16 \pm 14.18$ years ranging from 31-55 years, which shows that ESRD is most common among middle age adult group. Our findings in this respect are similar to those reported by Uchino et $a l^{8}$, (mean age $=44$ years), while contradict with findings of the study by Sood et al, and Apel et al, which reported mean age of ESRD patients as 74 and 62.4 years, respectively ${ }^{11,12}$. Many other studies, mostly
Table-II: Comparison of survivors and non-survivors for qualitative variables.

\begin{tabular}{|c|c|c|c|}
\hline $\begin{array}{l}\text { Parameter of } \\
\text { Interest }\end{array}$ & $\begin{array}{l}\text { Survivors } \\
(\mathrm{n}=140)\end{array}$ & $\begin{array}{c}\text { Non } \\
\text { Survivors } \\
(n=65)\end{array}$ & $\begin{array}{c}p- \\
\text { value }\end{array}$ \\
\hline \multicolumn{4}{|l|}{ Gender } \\
\hline Male & $80(57.1)$ & $37(56.9)$ & \multirow{2}{*}{0.976} \\
\hline Female & $60(42.9)$ & $28(43.1)$ & \\
\hline $\begin{array}{l}\text { Patients on mecha- } \\
\text { nical ventilation }\end{array}$ & $14(10)$ & $20(30.8)$ & $<0.001$ \\
\hline $\begin{array}{l}\text { Patients on } \\
\text { inotropic support }\end{array}$ & $34(24.3)$ & $33(50.8)$ & $<0.001$ \\
\hline Diabetes & $42(30.2)$ & $31(47.7)$ & $<0.05$ \\
\hline Hypertension & $78(55.7)$ & 47 (72.3) & $<0.05$ \\
\hline Stroke & $7(5)$ & $8(12.3)$ & 0.064 \\
\hline $\begin{array}{l}\text { Autoimmune } \\
\text { disease }\end{array}$ & - & $1(1.5)$ & 0.141 \\
\hline $\begin{array}{l}\text { Renal Stone } \\
\text { Disease }\end{array}$ & $8(5.7)$ & $4(6.2)$ & 0.787 \\
\hline $\begin{array}{l}\text { Polycystic kidney } \\
\text { disease }\end{array}$ & $2(1.4)$ & - & 0.333 \\
\hline $\begin{array}{l}\text { Chronic glomeru- } \\
\text { lonephritis }\end{array}$ & $3(2.1)$ & $2(3.1)$ & 0.687 \\
\hline
\end{tabular}

Table-III: Comparison of survivors and non-survivors for quantitative variables.

\begin{tabular}{|c|c|c|c|}
\hline Variables & Outcome & $\begin{array}{l}\text { Median } \\
\text { (IQR) }\end{array}$ & $\begin{array}{c}p- \\
\text { value }\end{array}$ \\
\hline \multirow{3}{*}{ Age in years } & Alive & $42.3(30-53)$ & \multirow{3}{*}{$<0.05$} \\
\hline & Expired & $48.3(38.5-60)$ & \\
\hline & Alive & $3.9(2-5)$ & \\
\hline \multirow{2}{*}{ ICU Stay } & Expired & $3.7(2-5)$ & \multirow{2}{*}{0.161} \\
\hline & Alive & $15.9(9.4-20.5)$ & \\
\hline \multirow{2}{*}{$\begin{array}{l}\text { Total Leucocyte } \\
\text { count }\end{array}$} & Expired & $16.4(10.7-21)$ & \multirow{2}{*}{0.480} \\
\hline & Alive & 14.5 (7-18) & \\
\hline \multirow{2}{*}{ Bicarbonate } & Expired & $16.3(8.5-16)$ & \multirow{2}{*}{0.552} \\
\hline & Alive & $8.5(7-10)$ & \\
\hline \multirow{2}{*}{$\begin{array}{l}\text { Total mean SOFA } \\
\text { score on 1st day }\end{array}$} & Expired & $11.9(8-16)$ & \multirow{2}{*}{$<0.001$} \\
\hline & Alive & $4.8(4-5)$ & \\
\hline $\begin{array}{l}\text { Total mean SOFA } \\
\text { score on last day }\end{array}$ & Expired & $14.6(13-17)$ & $<0.001$ \\
\hline
\end{tabular}

from Western countries, have also reported higher mean age of such patients ${ }^{13-15}$. Even, Juneja et al, from neighboring India has also reported a higher mean age of 54.1 years $^{16}$. The exact reason for the lower age of patients in our cohort is not known.

In our study, $117(57.1 \%)$ were males, which is same as reported by Bell et al ${ }^{13},(58 \%)$ and Dara et al ${ }^{17}$, (58\%). Bagsha et al ${ }^{14},(62 \%)$, Chapman et al ${ }^{15},(65 \%)$ and Juneja et $a^{16}$, also reported high proportion of male ESRD patients. 
Different studies have reported different outcomes in ESRD individuals ${ }^{7,18-22}$. Many studies have reported ICU mortality as well as hospital mortality and 30-day mortality ${ }^{7}$. We assessed only ICU mortality and related parameters in this study.

Mean ICU stay in our study was $3.8 \pm 2.8$ days ranging from 2-5 days which is higher than mean ICU stay reported by Juneja et $a l^{16}$, and Ostermann et al23, and lower than that reported by Chapman et al ${ }^{15}$, and Manhes et al18.

Current studies among ESRD patients enrolled in ICU provide useful information about mortality rates ${ }^{19-}$ ${ }^{23}$. The rates of admission of ESRD patients to ICU are higher compared with the general population ${ }^{16}$. In our study, the mortality rate among ESRD patients admitted in the ICU was $31.7 \%$, which is quite high. The reported ICU mortality is higher in our study compared to other hospital-based studies, 70,23 . This may be due to the fact that we had relatively advanced disease patients, which is reflected in the higher mean SOFA score of 9.58 on 1st day of admission in our study. On the other hand, mortality rates, reported in the present study, are similar to some other studies that reported the outcome of ESRD in the ICU population 7,11,20,21. These studies reported crude ICU mortality rates for ESRD ranging from 9-52.6\%, bracketing our estimate of $31.7 \%$.

Among non-survivors, $20(30.8 \%)$ required MV while $33(50.8 \%)$ were on inotropic support. Juneja et $a l^{16}$, reported mortality rate of $76.7 \%$ for patients requiring $\mathrm{MV}$ and $73.3 \%$ for those in need of inotropic support, which is very high as compared with our findings. Goswami et al21, reported increased need for organ support among non-survivors, as evidenced by the number of patients requiring invasive MV $(57 \%)$ and inotropic support (67\%)among expired patients.

Hypertension, diabetic nephropathy and renal stone disease were found as the most common comorbid conditions in our study population. A study from India, reported diabetic nephropathy (56\%) and hypertensive nephropathy $(17 \%)$ as the two most common causes of ESRD ${ }^{16}$. Despite the absence of any registry in Asia, diabetes and hypertension have been reported to be the cause of ESRD in $30-40 \%$ and $20 \%$ of cases, respectively, in another study from India ${ }^{21}$. Similarly, these diseases were highly prevalent among the known causes of ESRD in a previous study from our center ${ }^{24}$.

The indications for ICU admission in patients of ESRD in this study included severe metabolic acidosis, altered sensorium, sepsis, convulsions, shock, pulmonary edema and respiratory failure. Other studies have also found similar indications, although with variable frequencies and order ${ }^{14-20}$. As an example, Juneja et al, found respiratory failure as the most common indication for ICU admission ${ }^{16}$. Respiratory failure was the least common indication for ICU admission in our study. Sepsis was primarily related to dialysis catheters or infected Continuous Ambulatory Peritoneal Dialysis (CAPD) catheters. One of the study reported sepsis as second most common cause of ICU admission $^{14}$. Multiple factors affect the increased susceptibility to sepsis which include presence of soluble plasma tumour necrosis factor receptors, auto antibodies to anti-IL1a, an endogenous inhibitor of nitric oxide synthase, accumulation of asymmetric dimethylarginine, anaemia, trace element deficiencies, defects in opsonization of pathogens and aetiological factors responsible for the renal failure such as diabetes mellitus ${ }^{23,25}$.

The prediction of ICU results is fraught with uncertainty. One of the most effective ways to deal with uncertainty is to develop probabilistic models. Such models are useful in assessing the severity of disease on an applied scale, such as the probability of death.

Various different prognostic models have been developed to predict the outcome of critically ill patients entering the ICU. These systems allow us to identify the factors that influence the outcome, which vary between patients, and can be standardized to allow comparisons between patients. SOFA score is such an easy-to-use tool that has excellent diagnostic capabilities and is used to better the judgment in reaching the diagnosis as well provide the patients and their families with a much clearer picture of the outcome of the patient ${ }^{9}$. Higher median values of SOFA score were found in our study for expired patients. SOFA score also accurately predicted mortality and was found helpful by other investigators ${ }^{9,10,21}$.

SOFA score was reported to be significantly higher in non-survivors in comparison to those who survived $^{21}$. It is observed that ESRD patients requiring ICU critical care were unwell to a much higher degree and also suffered from multiple co-morbidities that led to higher score at the time of admission. There is also the possibility of delayed referral due to a much strict criteria for ICU admission with the understanding that CKD patients should be in a much more critical condition to be accepted in the ICU. The 30-day non-survivors required more frequent MV and vasopressors, suggesting greater severity of disease ${ }^{21}$. 


\section{ACKNOWLEDGEMENT}

This study was made possible by the help of Prof. Dr. Rubina Naqvi and Dr. Tabassum. We also greatly acknowledge Prof. Dr. Muhammed Mubarak for his help in preparing the final manuscript for publication.

\section{CONCLUSION}

High mortality rate was observed for ESRD patients admitted to ICU. High SOFA score was observed among patients who expired.

\section{CONFLICT OF INTEREST}

This study has no conflict of interest to be declared by any author.

\section{REFERENCES}

1. Saran R, Robinson B, Abbott KC, Bragg-Gresham J, Chen X, Gipson D, et al. US Renal Data System 2019 Annual Data Report: epidemiology of kidney disease in the United States. Am J Kidney Dis 2020; 75(suppl 1): S6-S7.

2. George C, Mogueo A, Okpechi I, Echouffo-Tcheugui JB, Kengne AP. Chronic kidney disease in low-income to middle-income countries: the case for increased screening. BMJ Global Health 2017; 2(2): e000256-65.

3. Evans K, Pyart R, Steenkamp R, Whitlock T, Stannard C, Gair R, et al. UK Renal Registry 20 $0^{\text {th }}$ Annual Report: Introduction. Nephron 2018; 139 (Suppl-1): 1-12.

4. Imtiaz S, Salman B, Qureshi R, Drohlia MF, Ahmad A. A review of the epidemiology of chronic kidney disease in Pakistan: A global and regional perspective. Saudi J Kidney Dis Transpl 2018; 29(6): 1441-51.

5. Bertram L, David C, Omar I, Jadoul M, Adler S, Jenkins S, et al. Improving Global Outcomes (KDIGO) CKD work group. kdigo 2012 clinical practice guideline for the evaluation and management of chronic kidney disease. Kidney Int Suppl 2013; 3(1): 1150.

6. Navva PK, Sreepada SV. Present status of renal replacement therapy in asian countries. Blood Purif 2015; 40(4): 280-87.

7. Chan M, Ostermann M. Outcomes of chronic hemodialysis patients in the intensive care unit. Crit Care Res Pract 2013; 2013(1): 715807-10.

8. Uchino S, Morimatsu H, Bellomo R, Silvester W, Cole L. Endstage renal failure patients requiring renal replacement therapy in the intensive care unit: incidence, clinical features, and outcome. Blood Purif 2003; 21(2): 170-75.

9. Vincent JL, Moreno R, Takala J, Willatts S, De Mendonça A, Bruining $\mathrm{H}$, et al. The SOFA (sequential organ failure assessment) score to describe organ dysfunction/failure. On behalf of the Working Group on Sepsis-Related Problems of the European Society of Intensive Care Medicine. Inten Care Med1996; 22(7): 707-10.

10. Ferreira FL, Bota DP, Bross A, Melot C, Vincent JL. Serial evalua- tion of SOFA score to predict outcome in critically ill patients. J Am Med Assoc 2001; 286(14): 1754-58.

11. Sood MM, Roberts D, Komenda P, Bueti J, Reslerova M, Mojica J, et al., End-stage renal disease status and critical illness in the elderly. Clin J Am Soc Nephrol 2011; 6(3): 613-19.

12. Apel M, Maia VP, Zeidan M, Schinkoethe C, Wolf G, Reinhart K, et al. End-stage renal disease and outcome in a surgical intensive care unit. Crit Care 2013; 17(6): R298-206.

13. Bell M, Granath F, Schon S, Lofberg E, Ekbom A, Martling CR. End-stage renal disease patients on renal replacement therapy in the intensive care unit: short-and long-term outcome. Crit Care Med 2008; 36(10): 2773-78.

14. Bagshaw SM, Mortis G, Doig CJ, Godinez-Luna T, Fick GH, Laupland KB. One-year mortality in critically ill patients by severity of kidney dysfunction: a population-based assessment. Am J Kidney Dis 2006; 48(3): 402-409.

15. Chapman RJ, Templeton M, Ashworth S, Broomhead R, McLean A, Brett SJ. Long-term survival of chronic dialysis patients following survival from an episode of multipleorgan failure. Crit Care 2009; 13(3): R65-68.

16. Juneja D, Prabhu MV, Gopal PB, Mohan S, Sridhar G, Nayak KS Outcome of patients with end stage renal disease admitted to an intensive care unit in India. Ren Fail 2010; 32(1): 69-73.

17. Dara SI, Afessa B, Bajwa AA, Albright RC. Outcome of patients with end-stage renal disease admitted to the intensive care unit. Mayo Clin Proc 2004; 79(11): 1385-13.

18. Manhes G, Heng AE, Aublet-Cuvelier B, Gazuy N, Deteix P, Souweine B. Clinical features and outcome of chronic dialysis patients admitted to an intensive care unit. Nephrol Dialysis Transplant 2005; 20(6): 1127-33.

19. Senthuran S, Bandeshe H, Ranganathan D, Boots R. Outcomes of dialysis patients with end-stage renal disease admitted to an Intensive Care Unit or high dependency unit. Med J Aust 2008; 188(5): 292-95.

20. Akbaş T, Karakurt S, Tuğlular S. Renal replacement therapy in the ICU: comparison of clinical features and outcomes of patients with acute kidney injury and dialysis-dependent end-stage renal disease. Clin Exp Nephrol 2015; 19(4): 701-709.

21. Goswami J, Balwani MR, Kute V, Gumber M, Patel M, Godhani U. Scoring systems and outcome of chronic kidney disease patients admitted in intensive care units. Saudi J Kidney Dis Transpl 2018; 29(2): 310-17.

22. De Rosa S, Samoni S, Villa G, Ronco C. Management of chronic kidney diseasepatients in the intensive care unit: mixing acute and chronic illness. Blood Purif 2017; 43(1-3): 151-62.

23. Ostermann M, Chang R. Renal failure in the intensive care unit: acute kidney injury compared to end-stage renal failure. Crit Care 2008; 12(5): 432-35.

24. Manzoor K., Rizvi SA. Causes of chronic renal failure in Pakistan: a single large center experience. Saudi J Kidney Dis Transpl 2002; 13(3): 376-79.

25. Kao CC, Yang JY, Chen L, Chao CT, Peng YS, Chiang CK, et al. Factors associated with poor outcomes of continuous renal replacement therapy. PLoS ONE 2017; 12(5): e0177759-70. 